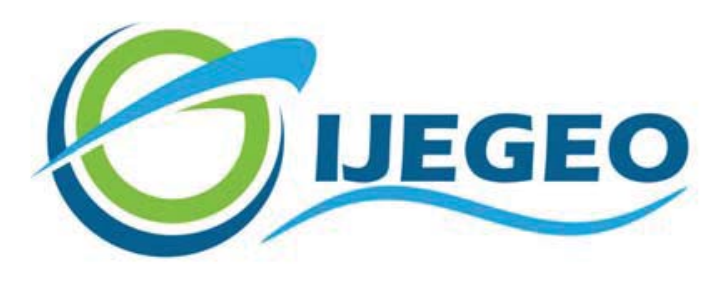

International Journal of Environment and Geoinformatics (IJEGEO) is an international, multidisciplinary, peer reviewed, open access journal.

\title{
Improvement of the Environmental Permit and License Application Process in Turkey
}

\author{
Asude HANEDAR, Ayşegül TANIK, Yalçın GÜNEŞ, Elçin GÜNEŞ, Gül KAYKIOĞLU, \\ Erdem GÖRGÜN, Uğur ÖZYURT, Sibel YURTSEVER, Hasan SEÇGİN, Özgür \\ SOLAK, Alev PIRCI, Özlem YILMAZ, Tülay KIRIMHAN, Fatma ERDEM, Erhan \\ SARIOĞLU, Ali DURAK, Yahya KESIMAL, Mehrali ECER, Mehmet Emin BİRPINAR
}

\author{
Chief in Editor \\ Prof. Dr. Cem Gazioğlu \\ Co-Editors \\ Prof. Dr. Dursun Zafer Şeker, Prof. Dr. Şinasi Kaya, \\ Prof. Dr. Ayşegül Tanık and Assist. Prof. Dr. Volkan Demir
}

Editorial Committee (September 2021)

\begin{abstract}
Assoc. Prof. Dr. Abdullah Aksu (TR), Assit. Prof. Dr. Uğur Algancı (TR), Prof. Dr. Bedri Alpar (TR), Assoc. Prof. Dr. Aslı Aslan (US), Prof. Dr. Levent Bat (TR), Prof. Dr. Paul Bates (UK), İrşad Bayırhan (TR), Prof. Dr. Bülent Bayram (TR), Prof. Dr. Luis M. Botana (ES), Prof. Dr. Nuray Çağlar (TR), Prof. Dr. Sukanta Dash (IN), Dr. Soofia T. Elias (UK), Prof. Dr. A. Evren Erginal (TR), Assoc. Prof. Dr. Cüneyt Erenoğlu (TR), Dr. Dieter Fritsch (DE), Prof. Dr. Çiğdem Göksel (TR), Prof.Dr. Lena Halounova (CZ), Prof. Dr. Manik Kalubarme (IN), Dr. Hakan Kaya (TR), Assist. Prof. Dr. Serkan Kükrer (TR), Assoc. Prof. Dr. Maged Marghany (MY), Prof. Dr. Michael Meadows (ZA), Prof. Dr. Nebiye Musaoğlu (TR), Prof. Dr. Masafumi Nakagawa (JP), Prof. Dr. Hasan Özdemir (TR), Prof. Dr. Chryssy Potsiou (GR), Prof. Dr. Erol Sarı (TR), Prof. Dr. Maria Paradiso (IT), Prof. Dr. Petros Patias (GR), Prof. Dr. Elif Sertel (TR), Prof. Dr. Nüket Sivri (TR), Prof. Dr. Füsun Balık Şanlı (TR), Prof. Dr. Uğur Şanlı (TR), Duygu Ülker (TR), Prof. Dr. Seyfettin Taş (TR), Assoc. Prof. Dr. Ömer Suat Taşkın (TR), Assist. Prof. Dr. Tuba Ünsal (TR), Dr. Manousos Valyrakis (UK), Dr. İnese Varna (LV), Dr. Petra Visser (NL), Prof. Dr. Selma Ünlü (TR), Assoc. Prof. Dr. Oral Yağcı (TR), Prof. Dr. Murat Yakar (TR), Assoc. Prof. Dr. İ. Noyan Yılmaz (AU); Assit. Prof. Dr. Sibel Zeki (TR)
\end{abstract}




\title{
Improvement of the Environmental Permit and License Application Process in Turkey
}

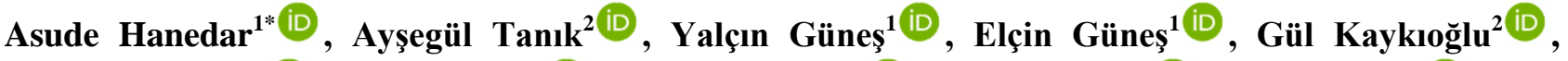

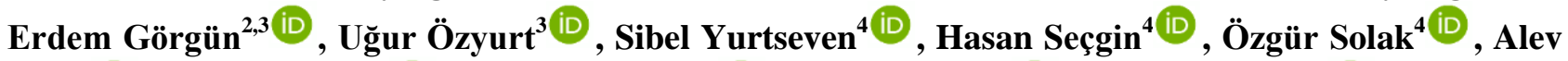

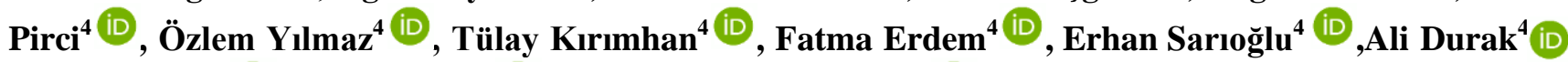 \\ Yahya Kesimal ${ }^{\text {iD, }}$ Mehrali Ecer ${ }^{4}$ (iD), Mehmet Emin Birpınar ${ }^{5}$ iD
}

\footnotetext{
${ }^{1}$ Department of Environmental Engineering, Çorlu Faculty of Engineering, Tekirdağ Namık Kemal University, Tekirdağ, Turkey

${ }^{2}$ Department of Environmental Engineering, Faculty of Civil Engineering, Istanbul Technical University, Istanbul, Turkey

${ }^{3}$ io Environmental Solutions, Istanbul/Turkey

${ }^{4}$ Ministry of Environment and Urbanization, General Directorate of Environmental Impact Assessment, Permit and Inspection, Ankara, Turkey

${ }^{5}$ Ministry of Environment and Urbanization, Vice Minister, Ankara, Turkey
}

* Corresponding author: A. Hanedar

Received 30 Jan 2020

E-mail: ahanedar@nku.edu.tr

How to cite: Hanedar et al., (2021). Improvement of the Environmental Permit and License Application Process in Turkey, International Journal of Environment and Geoinformatics (IJEGEO), 8(3):307-315. doi. 10.30897/ijegeo.871085

\begin{abstract}
Improvement on the environmental permit application that has been put into force since 2014 by the By Law on Environmental Permit and License (BLEPL) in Turkey has been achieved through a project realized by the Ministry of Environment and Urbanization to meet the developing and changing technology, and industry needs. The main outputs derived from this project will be briefly outlined and discussed in this study. Initially, the facility inventory lists were created on provincial basis across the country. The related institutions were then contacted, and the provincial and sectoral information of the enterprises that could be within the scope of BLEPL was obtained. On the country basis, 548.323 facilities were evaluated in which 142.477 facilities were classified as permitted, out of scope, in scope and not permitted. According to the data obtained by compiling the facility inventories within the scope of BLEPL constituted only $15 \%$ of the existing facilities that were included in the scope of the permit. Annex-1 and Annex-2 of BLEPL were also revised. Moreover, each of the items in the annex lists were evaluated separately and the necessary scope/limit/threshold value/terminology revisions were made. By the amendments made in the annex lists; the number of items decreased to 245 from 272, 24 new items were added and 21 items were removed. Within the study, sectoral guidelines were prepared for each additional item to ensure integrity in permit-license applications throughout the country, and to conduct a scoping study based on accurate, practical and specific standards. Other work packages completed can be addressed as the support, credit and incentive processes carried out by institutions and organizations to increase the efficiency of the documents organized in the implementation of the regulation, studies for searching the documents in question in public tenders, and making suggestions to improve the processes and procedures that the facilities are subject to.
\end{abstract}

Keywords: Environmental permit, Environmental license, Facility inventory, Permit/license process.

\section{Introduction}

Ecological degradation, environmental pollution and resource overexploitation have been regarded as the most critical constraints for sustainable development all over the world. For this purpose, governments have attempted to solve or mitigate the environmental problems through forming an effective, integrated and applicable environmental regulation system (Tian et al., 2019; Wang et. al. 2020; Ahmetoğlu and Tanık, 2020).

The first pollution prevention at industrial level in Europe was initiated with the Integrated Pollution Prevention and Control (IPPC) Directive launched in 1996 (EC, 1996; Ülker et al., 2018). The basic aim of this directive was to inspire continuous environmental performance by requiring public access to licensing information (Silvo et. al., 2002; Bello Bugallo et. al., 2013). EU has then updated this framework in 2010 by the publication of the Directive 2010/75/EU on industrial emissions (EU, 2010; Mersin et al., 2019-2020). Even though the member states have introduced some different regulations specific to their countries, they generally adapted the requirements of this directive into their national legislation and developed an integrated emission permit system (Farmer et. al., 2010; Ülker et al., 2020; Tokuşlu et al., 2020).

For example, in Belgium, although the permit systems are operated differently for the three main regions (Flemish, Walloon and Brussels Metropolitan), industrial facilities obtain an integrated and single permit from the competent authorities that takes into account all environmental impacts of the facility. In Germany, where environmental law is strictly implemented, environmental problems are increasingly affected by EU law, although they are mainly regulated by the national legislation. There is no central administrative 
organization in Germany, the state officials carry out operational activities. There is an integrated permit regime (OECD, 2007; Farmer et. al., 2010). There are two separate environmental permit regimes in France, both private and integrated. Activities not covered by the integrated permit regime, such as mining and nuclear activities, require special permits. The estimated time limit for reviewing an application for an integrated permit is nine months. Environmental Permit Regulations in England and Wales have an integrated environmental permit regulation based on the EU law. Although there is generally a central administrative system, some less polluting activities can be regulated by local authorities (Taylor et. al., 2012; Akyüz, 2021).

Non-EU countries, for example Russian Federation, revised its environmental permit system as of January 1, 2019. An integrated permit system has been introduced for industrial facilities with high pollutant emissions, and permit procedures for other categories have been simplified. In this new system, facilities are classified into four categories, with different levels of regulatory obligations for each category. While Category I facilities are required to obtain a single integrated environmental permit instead of separate permits, Category III and IV facilities do not have to obtain environmental permits or make statements about environmental impact.

The laws and regulations adopted on the environment in the USA are carried out by the Environmental Protection Agency (EPA). There is no integrated environmental permit in the USA. In Canada, in general, each province has its own environmental permit regime and does not have an integrated permit system.

There are different practices at the state level in Brazil. For example, in Sao Paulo State, the environmental permitting process was renewed in 2005. The new permit system was organized in three successive stages: pre-permission, installation permit, operation permit (Riberio and Krunglianskas, 2013).

China, confronting with increasing environmental problems, have experienced significant developments in integrated environmental permit regulations. Regional arrangements were adopted from environmental function regions in the $1990 \mathrm{~s}$ to Environmental Impact Assessment (EIA) planning in 2003, to the national ecological function region in 2008, and to the implementation of the Red Line for Ecological Conservation (RLEC) in 2011. Three Lines One Permit (TLOP), which is a more comprehensive and systematic environmental zoning system, has then been implemented in 2012. TLOP includes a red line for ecological conservation, a lower line for environmental quality named as Bottom Line for Environmental Quality (BLEQ), and an Upper-limit Line for Resource Use (ULRU). The country classifies its activities according to these restrictions (Zhou et. al., 2019; Wang et al., 2020).

Although there are differences from country to country and even between states, the purpose of all environmental permit and license procedures is to reduce the environmental impact of industrial activities and to carry out activities in accordance with the prevailing environmental conditions. In order to establish the principles of an effective environmental permit system, it is important to prepare reference documents suitable for use by the governments and various stakeholders, to ensure compliance of regulations with new systems, to create a high level of political and institutional awareness and support, and to share experiences and contributions between institutions.

An appropriate environmental permit and license process should be able to include all fixed resources that have an environmental impact and should take into account all environmental impacts. In addition, it should be able to make a correct distinction between activities by rating the impact of the activity with accurate, scientific, up-todate data. Similarly, permit requirements should be clear and understandable. The duration of the leave, validity and termination conditions, and the rules to be applied in case of a change in the activity should be clearly and comprehensibly expressed. It should be a transparent practice, carried out in parallel with the environmental impact assessment process, to standardize the scope of discretion of the practitioners as much as possible (Chakrabarti and Mitra, 2005).

In Turkey, By Law on Environmental Permit and License (BLEPL) has been implemented and put into force in 2014. A comprehensive and holistic approach to environmental permit/license systems has then been achieved by seeking a single environmental permit to prevent, reduce and control the pollution caused by any activity through the application of this regulation. However, an updating in the regulation was required to meet the developing technology and industry needs, and to overcome the difficulties in implementation since 2014. The constraints experienced in environmental permit and license applications were lack of a nationwide facility inventory, problems in obtaining and renewing the environmental permit-license certificate, disruptions in the documentation network system between state institutions, and the confusion faced about the additional lists of the permitted facilities. Problems encountered with the Annex lists may be summarized as follows;

- The current terminology was not sufficiently comprehensive,

- The limit/threshold values were unsuitable, some of the activities were overlapping with others, for some substances different applications were carried out due to insufficient clarity and comprehensibility,

- The problems identified in the applications were related to the waste type, and many incompatibilities were faced with the EIA Regulation.

In this context, General Directorate of Environmental Impact Assessment, Permit and Inspection of the TR Ministry of Environment and Urbanization (MoEU) has recently completed the Improvement of Environmental 
Permits and Licenses Project. The main aim of the project was the improvement and development of BLEPL application in the country. The milestones of the project and the outputs derived will be briefly outlined and discussed in this study. More effective and efficient environmental permit/license process can be encountered through an inventory of facilities subject to environmental permit/license; revision of the threshold/limit value of the supplementary lists of facilities or activities, rearranging scope and terminology, preparation of sectoral guidelines on the basis of the annex lists, revision of the implementation process of the regulation and of the requested documents, and by putting forth the suggestions for increasing the efficiency of the issued documents.

\section{Materials and Methods}

In Turkey, BLEPL regulates the principles on the operations that are subject to environmental permit and/or license (EPL), authorizes the officials that issue Provisional Activity Certificate (PAC) and EPL together with the officials that evaluate the applications belonging to PAC, and decides on applicants for environmental permit and/or license.

BLEPL also states how to arrange the documents, the validity and renewal conditions of the environmental permit and licence certificate (EPLC), how to act in case the owner or title of the enterprise holding the environmental permit and/or license certificate changes, how to cancel the EPLC and the transactions related to facilities that started operations without PAC, how to decide on provisions and limitations that businesses that are not subject to environmental permit must comply, and how to act in case of termination of the activity.
The regulation has three attachments:

- Annex-1 refers to the list of enterprises with high level of polluting effect on the environment,

- Annex-2 lists the enterprises with polluting effects on the environment, and

- Annex-3A-3B outlines PAC application form and attachments whereas Annex-3C covers information and documents that must be submitted during the completion of the environmental permit and license process.

The activities and facilities listed in Annex-1 and Annex2 of BLEPL are responsible for all works and procedures regarding the permits and licenses required by the Environmental Law of Turkey with No. 2872. In these annexes, facility types with high environmental impact (Annex-1) and environmental impact (Annex-2) are classified under 10 sectoral headings with the limits and threshold values. Annex lists include all activities that have emissions to the receiving environment and/or conduct operations from collection of wastes till final disposal stage, excluding transportation.

The main objectives to be achieved as a result of the study were:

- Conducting a facility inventory on a provincial basis across the country,

- Revising threshold values and terminologies used in additional items,

- Improving the procedure followed in the permit license process.

The pathway followed in improving the environmental permit and license is given in Figure 1.

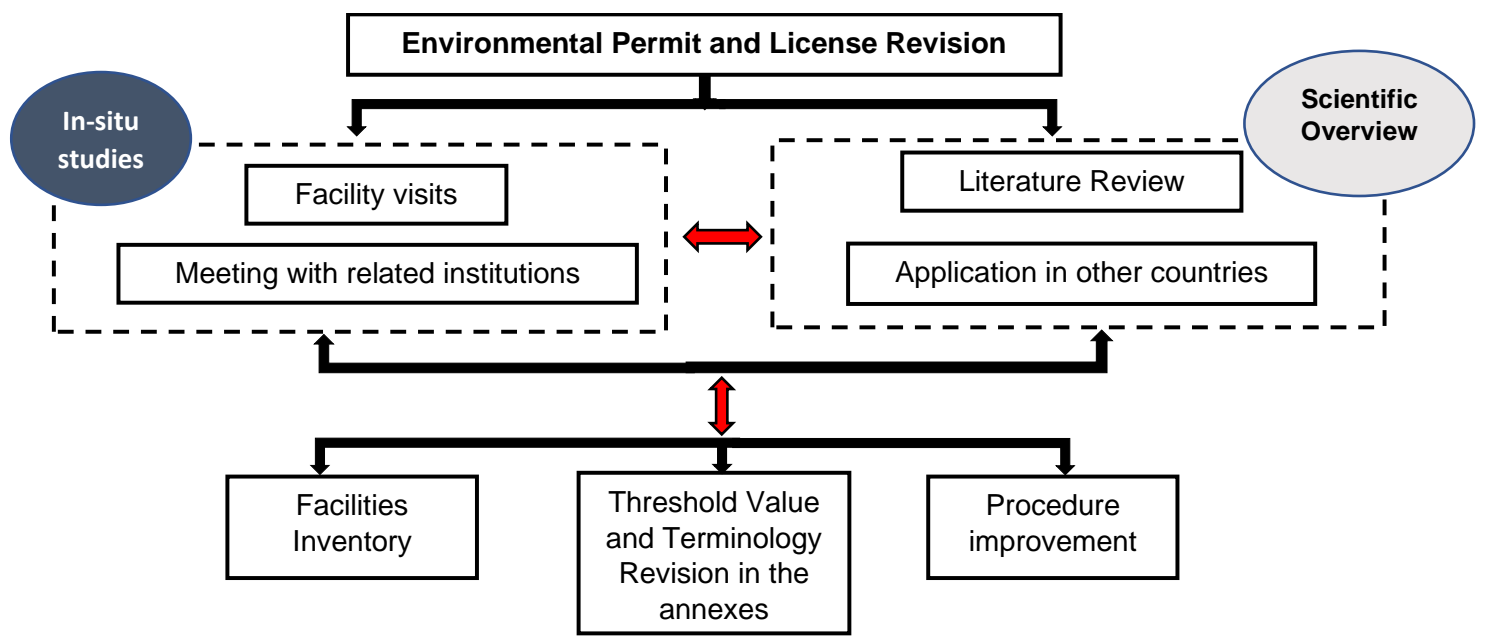

Figure 1. The pathway followed in improving the environmental permit and license procedure

\section{In-Situ Studies}

Within the scope of the study, 80 facility visits were realized in different cities in the country (Istanbul, Ankara, İzmir, Bursa, Kocaeli, Tekirdağ, Konya, Eskişehir, Kayseri, Adana and Bilecik) to handle a realistic improvement in the procedure, to better determine the permit-licensing process in practice, to solve the problems encountered by different stakeholders related to the process, and to ensure the involvement of the sector by taking some measures. The facilities experiencing frequent problems with Annex-1 and Annex-2 lists were selected for the visits.

Throughout the project, 11 meetings, 1 workshop and 1 training program were held with members of each Provincial Directorates of the MoEU (PDoEU), sector 
representatives, environmental consultancy firms, and with the officials from the other related ministries/institutions/organizations. Within the scope of the study, another technical visit was also realized to Germany in March 2020 to three facilities and some meetings were realized with the authorities to learn more on the process of environmental permit and licensing in Germany.

\section{Scientific Overview}

Studies were carried out for each sector whose permit principles were determined under the current headings given in the annexes of the regulation. In this context, the definition of the activities under each heading, the current application level of the regulation for the relevant activity, and the needs for further analysis were realized. The steps followed are similar to those referred by Bello Bugallo et. al. (2013); Söderholm et. al. (2015); Lopes et. al. (2017).

i. General analysis of the sector: This step mentions a general vision of the industry including the classification and characterization of the sub-sector(s).

ii. Analysis of the generic process: An analysis of the generic industrial process is made for each subheading, where the typical stages of the process are identified, classified and described in a flow diagram. These will be related to the most relevant environmental aspects for the sector.

iii. Compilation of facility visit data: Data obtained from facility visits are compiled.

iv. Environmental Impacts: This step includes the evaluation of the environmental impacts associated to each sub-heading. Emissions to air and water, and data on waste generated are compiled from facility's permit documents, and most of them are calculated on the basis of emissions factors. Analyses on the Best Available Techniques (BAT) were done for each sub-heading. These techniques ensure minimum environmental impact of the installation (EC, 2006; Georgopoulou et al., 2008).

\section{Results}

\section{Facilities Inventory}

Principles taken into account identified those facilities that were subject to environmental permit, but have not yet applied for permit. Facilities that have already obtained environmental permit in the country were excluded. Determination of the sectors and provinces on which the relevant facilities were concentrated, and resolving additional scopes related to these facilities were realized. Outputs were put forth based on these criteria. The following steps have been followed:
- Annexed lists of BLEPL were examined and the relevant institutions and organizations to be contacted were determined (such as Ministry of Energy and Natural Resources, Ministry of Culture and Tourism, Ministry of Health, Ministry of Agriculture and Forestry, Turkish Statistical Institute, Union of Chambers and Commodity Exchanges of Turkey etc.).

- By contacting the relevant institutions and organizations, draft lists of the enterprises that can be included in the scope of BLEPL were prepared on the basis of provinces and sectors, except for the facilities that have already obtained PAC or EPLC.

- The draft lists created were clarified by arranging regional meetings with the PDoEU. Through the clarified inventory lists, an evaluation was made based on the industries with high levels of pollution and businesses with a polluting effect on the environment.

- The inclusion of activity fields -determined as not included in the annexed lists in the previous step- in the regulation has been evaluated.

- On the basis of province and facility, a list of the information of the facilities with PAC or EPLC has been prepared.

As such, 548.323 facility data were obtained. A software was used to compile information such as address, province, district, title, production activity codes (PRODCOM-EU production statistics product classification), NACE codes and capacity. Initially, facilities were compared according to trade name, city and address, and the number of records in the data breakdown was determined as 142.477. In addition, the lists of the facilities that have applied to the MoEU to obtain PAC and EPLC were taken from the MoEU. The facilities have been screened according to commercial title, province and address. By eliminating duplicate registrations, the number of facilities registered in the system was reduced from 24.247 to 22.239 . In the last stage, 142.477 facilities, were compared with those obtained from the MoEU system. Facilities that did not match were separated based on provinces and sent to relevant provincial directorates, and remarks were gathered from the experts of the provincial directorates (as exempt, out of scope, duplicate, possible, permitted, closed).

The flow chart of the works carried out within the scope of the study is given in Figure 2. According to the results, the comparison of data obtained by compiling the facility inventories with the facilities that applied and have not applied within the scope of BLEPL was only $15 \%$ of the existing facilities in total. 


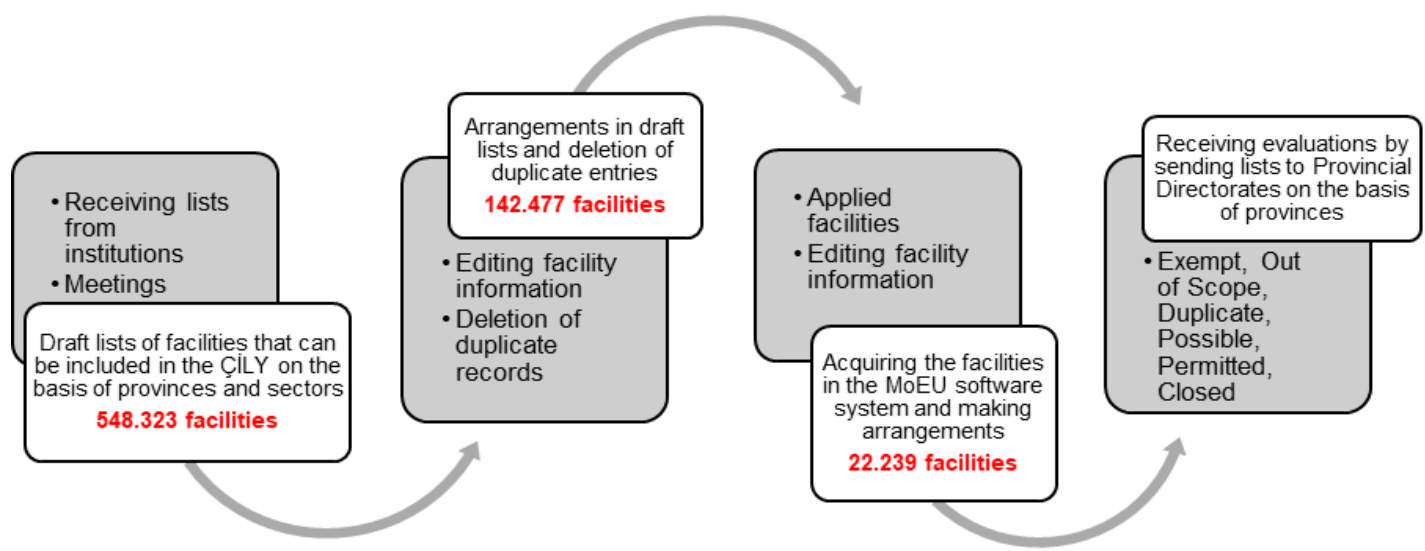

Figure 2. Flow chart illustrating the organization of facility inventories

\section{Revision on Threshold Values and Terminologies}

Annex lists consist of regulations for 10 different sector titles, as stated below:

1. Energy Industry

2. Mining and Construction Materials Industry

3. Metal Industry

4. Chemical and Petrochemical Industry

5. Surface Coating Industry

6. Forestry Products and Cellulose Plants

7. Food Industry, Agriculture and Farming

8. Waste Management

9. Storage, Loading and Unloading of Materials

10. Other Facilities

The activities carried out during the revision of threshold values and terminologies were:

- The facilities/activities, activity capacities, limits, threshold values, terminologies and exempted permit subjects were scientifically examined regarding their titles in the lists of Annex-1 and Annex-2. Editing/adding/removing activities from the lists were realized.

- Opinions of PDoEU were received within this scope.

- Comparisons were made regarding the environmental legislation in force and in draft form.

- 80 facilities representing different sectors and subsectors were visited and an abroad trip was organized.

The basic sources used within the scope of the revision process were information obtained from the facility visits; problems identified by MoEU, PDoEU and consultant firms; facility capacity data on province basis obtained through the inventory; number of permitted facilities obtained from MoEU, EIA Regulation and IPPC Regulation Draft annexes, other regulations of Turkey, outputs of similar other projects and existing literature data. The methodology followed within the revision step was briefly as given below:
I. Identification of the annex item: Sector titles and their order of listing in the annex have been taken into account. The number of sub-items and the corresponding items in Annex-1 and Annex-2 were presented, the concepts on which the items were based on were defined, and the ones determined from the PRODCOM codes and linked with each additional related item were presented.

II. Sectoral Assessment: relevant sector, general information, production subject, environmental impacts, air, water and solid waste emissions have been determined under each sectoral sub-title.

III. Sectoral Inventory Information: If necessary, re-determination of the threshold value, the capacity of the sector in the country and the number of facilities were taken into consideration. At this stage, the facility number, activity topic and capacity information provided from the Union of Chambers and Commodity Exchanges of Turkey (UCCE) were used.

IV. Determination of the revision proposal: All studies conducted up to this stage have been evaluated for each annex item. Revision in the annexes was proposed under the following circumstances:

i) If the necessity is demonstrated by the MoEU, MoEU experts or sector experts.

ii) If it is considered that the current limit and threshold values do not fully express the effect of the activity on the environment with the literature research.

iii) If considered incompatible with Turkey's average values regarding the environmental effects and the capacity value of the item.

V. Preparation of Sectoral Guidelines: These were prepared for each sector title. The sectoral guidelines whose image and corresponding content are given in Figure 3 were organized in a way to include the following information:

- General brief information about the sector subtitle,

- Terminology explanations in the relevant item,

- Scope of the relevant item, 
- Information on the types of facilities included and excluded

- If necessary, explanations and sub-information about the substance of concern,

- Environmental impacts of the industry.

Each item in the annex list was individually evaluated and the necessary arrangements were made. Resultantly, the number of items, which was 272 in total, decreased to 245 . The graphical presentation showing the comparison of the number of items before and after the revision is given in Figure 4. The changes made under each sector are summarized in Table 1. Considering the types of these changes, 25 items were combined and threshold value revisions were done in 27 items. The scope and definition of 149 items were arranged. 24 new articles were included to the annexes and 21 articles were removed.

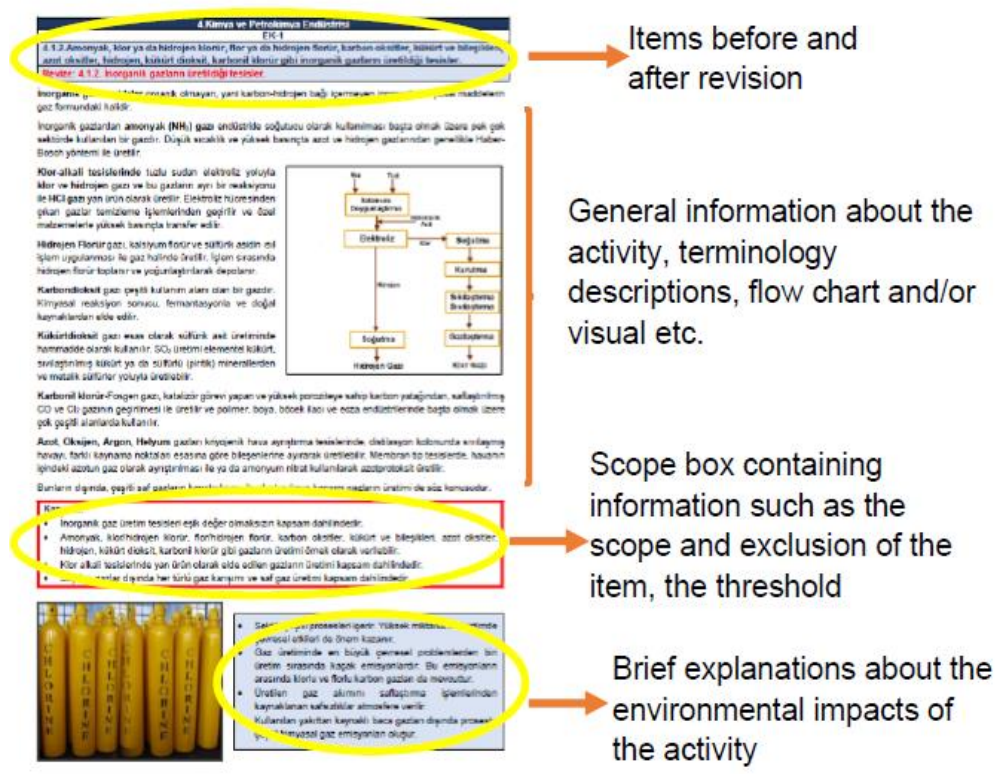

Figure 3. Explanations on sectoral guidelines prepared

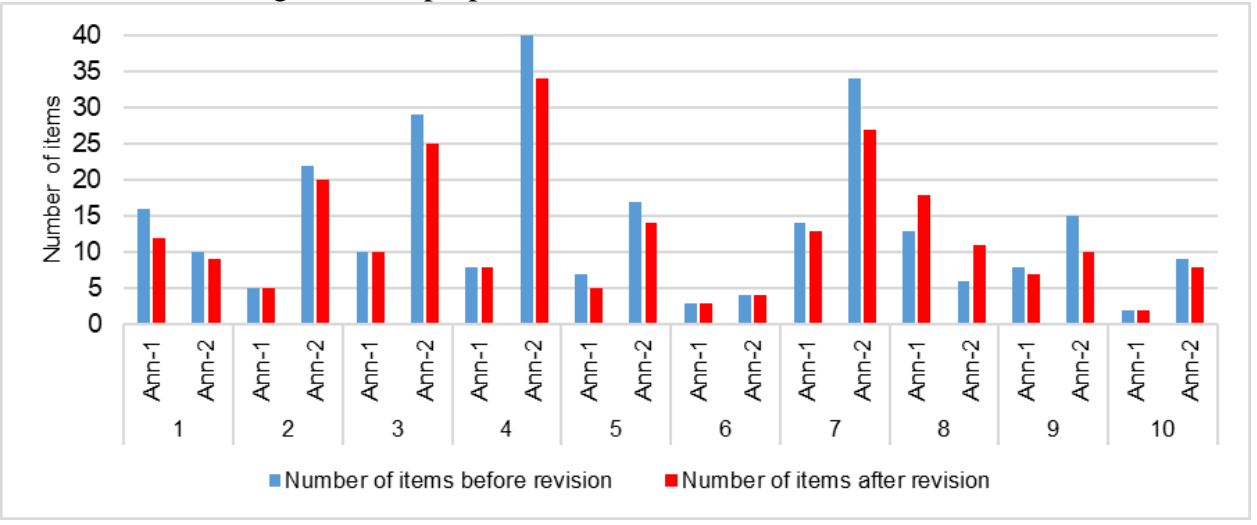

Figure 4. Comparison of the number of items before and after revision

\section{Improvement of the Procedure}

Within the scope of the study, revision suggestions were prepared by analysing the information and documents requested at every stage of the regulation's processes. The steps followed were as follows:

- Meetings were held with MoEU and PDoEU experts, representatives of the Provincial Directorate of Industry and Technology, representatives of the Chamber of Industry and Commerce and consultancy firms regarding the analysis of sectoral processes included in the regulation.

- At the meetings, the documents requested at the application stages were reviewed and the reasons for requesting these documents were presented. In order to reduce bureaucracy, the documents that should be directly requested from the applicant at the application stage have been determined.

- By conducting research on transferring the documents requested in PAC and EPL applications to electronic media, suggestions for probable solutions were determined.

It is predicted that the simplification to be provided in the duplicate documents requested in the process of obtaining the EPLC will positively affect the permit and license process. In the process of obtaining the Provincial Directorate Compliance Letter, it is important for the enterprise to meet the physical conditions of the activity to be carried out. As a result of the investigations made, it has been determined that the application process of the PAC and the Provincial Directorate's Compliance 
Table 1. Arrangements in Annexed Items.

\begin{tabular}{|c|c|c|}
\hline 1. Energy Industry & 4. Chemical and Petrochemical Industry & 6. Forestry Products and Cellulose Plants \\
\hline $\begin{array}{l}\text { The items related to thermal and heat power } \\
\text { plants and combustion systems were } \\
\text { combined and simplified. }\end{array}$ & $\begin{array}{l}\text { The definition and scope of integrated chemical } \\
\text { facilities has been changed. }\end{array}$ & $\begin{array}{l}\text { The threshold value for driving power available for } \\
\text { woodworking plants has been re-adjusted. } \\
\text { Production capacity was determined as a threshold } \\
\text { value. }\end{array}$ \\
\hline $\begin{array}{l}\text { The situation of burning "more than one } \\
\text { fuel" was added to combustion systems and } \\
\text { thermal power plant materials. }\end{array}$ & $\begin{array}{l}\text { The material threshold value for the production of } \\
\text { inorganic chemicals has been changed. }\end{array}$ & $\begin{array}{l}\text { The statement about waste paper in the item on } \\
\text { paper production has been re-arranged. }\end{array}$ \\
\hline $\begin{array}{l}\text { The item related to the combined cycle, } \\
\text { combined heat power plants, internal } \\
\text { combustion engines and gas turbines } \\
\text { generators were combined and simplified. }\end{array}$ & $\begin{array}{l}\text { Organic fertilizer production was added to the } \\
\text { fertilizer production and the scope was changed. }\end{array}$ & $\begin{array}{l}\text { Parquet production and chipboard production were } \\
\text { combined under the relevant item and the } \\
\text { threshold value was re-arranged. }\end{array}$ \\
\hline $\begin{array}{l}\text { Tar and natural asphalt processing were } \\
\text { combined. }\end{array}$ & $\begin{array}{l}\text { Simple hydrocarbon production and organic solvent } \\
\text { combined and changed to production of organic } \\
\text { chemicals. }\end{array}$ & $\begin{array}{l}\text { Parquet production and furniture production were } \\
\text { separated. Furniture production threshold has been } \\
\text { adjusted. The threshold value was determined on } \\
\text { the raw material capacity. }\end{array}$ \\
\hline $\begin{array}{l}\text { In gasification/liquefaction facilities, lower } \\
\text { threshold value was used. }\end{array}$ & $\begin{array}{l}\text { Distillation and refining processes of petroleum and } \\
\text { petroleum products have been excluded from this title } \\
\text { (Under Title 1) }\end{array}$ & 7. Food Industry, Agriculture and Farming \\
\hline $\begin{array}{l}\text { The article on geothermal power plants has } \\
\text { been added to Annex- } 2 \text {. }\end{array}$ & $\begin{array}{l}\text { The content of the item related to the textile sector } \\
\text { has been re-arranged. }\end{array}$ & $\begin{array}{l}\text { Crude oil production and refining processes were } \\
\text { separated and threshold values were changed. }\end{array}$ \\
\hline $\begin{array}{l}\text { 2. Mining and Construction Materials } \\
\text { Industry }\end{array}$ & $\begin{array}{l}\text { The item on leather production was taken from Title } 7 \\
\text { and added under this title. }\end{array}$ & $\begin{array}{l}\text { The item related to leather processing was placed } \\
\text { under the } 4^{\text {th }} \text { title. }\end{array}$ \\
\hline $\begin{array}{l}\text { The statement regarding glass } \\
\text { manufacturing facilities has been edited and } \\
\text { simplified. }\end{array}$ & $\begin{array}{l}\text { Paint, pigment polish, etc. for production an upper } \\
\text { threshold was added to ANNEX-1. The version in } \\
\text { ANNEX-2 has been re-arranged. }\end{array}$ & $\begin{array}{l}\text { Statements regarding animal breeding and } \\
\text { slaughtering facilities have been simplified. }\end{array}$ \\
\hline $\begin{array}{l}\text { Annex-2 grinding-packaging facilities were } \\
\text { combined and simplified. }\end{array}$ & $\begin{array}{l}\text { The title of production of plastic raw materials has } \\
\text { been clarified. Plastic raw materials were divided into }\end{array}$ & $\begin{array}{l}\text { Items related to animal waste have been combined } \\
\text { and the scope has been clarified. }\end{array}$ \\
\hline $\begin{array}{l}\text { The article on ceramic and/or porcelain } \\
\text { production has been regulated, and a lower } \\
\text { threshold value has been introduced in } \\
\text { Annex-2. }\end{array}$ & $\begin{array}{l}\text { sub-items and the scope was determined (polymer, } \\
\text { resin, rubber, cellulose nitrate). }\end{array}$ & $\begin{array}{l}\text { Olive processing and olive oil production were } \\
\text { separated and olive oil production was given a } \\
\text { threshold value in Annex- } 2 \text {. }\end{array}$ \\
\hline $\begin{array}{l}\text { New products were added to the production } \\
\text { of concrete elements. }\end{array}$ & $\begin{array}{l}\text { Soap and detergent production were combined, the } \\
\text { threshold value was renewed, and scope was } \\
\text { clarified. }\end{array}$ & $\begin{array}{l}\text { A lower threshold value was given for tea } \\
\text { production. }\end{array}$ \\
\hline $\begin{array}{l}\text { The item on asphalt plant facilities has been } \\
\text { edited. }\end{array}$ & $\begin{array}{l}\text { The items related to wood protection products were } \\
\text { combined and scope was clarified. }\end{array}$ & $\begin{array}{l}\text { A lower threshold was given for } 2 \text { items related to } \\
\text { beverage production. }\end{array}$ \\
\hline $\begin{array}{l}\text { The threshold value for mining and crushing } \\
\text { operations has been edited, simplified and } \\
\text { the scope was clarified. }\end{array}$ & $\begin{array}{l}\text { Soot and carbon black etc. items were combined. } \\
\text { The scope of the items has been clarified such as } \\
\text { pitch production. }\end{array}$ & $\begin{array}{l}\text { A new item on aquaculture activities has been } \\
\text { added. }\end{array}$ \\
\hline $\begin{array}{l}\text { Threshold value has been changed in the } \\
\text { marble processing facilities. }\end{array}$ & $\begin{array}{l}\text { A new item on processing plastic raw materials has } \\
\text { been added. }\end{array}$ & $\begin{array}{l}\text { A new item has been added regarding facilities } \\
\text { where vegetable and/or animal products were } \\
\text { processed, or directly canned and/or packaged. }\end{array}$ \\
\hline 3. Metal Industry & 5. Surface Coating Industry & 8. Waste Management \\
\hline $\begin{array}{l}\text { The item related to the production of scrap } \\
\text { iron and steel was changed as "having } \\
\text { secondary metal characteristics". }\end{array}$ & $\begin{array}{l}\text { Confusion with coating and polishing facilities has } \\
\text { been cleared out, definitions have been clarified and } \\
\text { their scope has been expanded. Some items in } \\
\text { Annex- } 1 \text { and Annex- } 2 \text { have been removed. }\end{array}$ & $\begin{array}{l}\text { Separate items for recovery and disposal facilities } \\
\text { are re-arranged in Annex-1. Waste disposal and } \\
\text { incineration and landfill facilities were considered } \\
\text { as separate items. }\end{array}$ \\
\hline $\begin{array}{l}\text { The scope for accumulator manufacturing } \\
\text { facilities has been clarified. }\end{array}$ & $\begin{array}{l}\text { The painting, polishing, coating and drying processes } \\
\text { were all evaluated on a single item. In this way, } \\
\text { separate items related to raw materials (material in } \\
\text { the form of profiles and bands, wood, etc.) were } \\
\text { removed. }\end{array}$ & $\begin{array}{l}\text { A threshold value was given for the recovery } \\
\text { facilities of paper and metal/slag non-hazardous } \\
\text { wastes in accordance with the } 3^{\text {rd }} \text { and } 6^{\text {th }} \text { titles of } \\
\text { the Regulation, and were determined as separate } \\
\text { substances in Annex-1 and Annex-2. }\end{array}$ \\
\hline $\begin{array}{l}\text { The threshold value for the tank volume in } \\
\text { coating plants has been reduced. The } \\
\text { expression has been clarified. }\end{array}$ & $\begin{array}{l}\text { The definition for rotary printing machines has been } \\
\text { clarified. The exemption statement for ethanol has } \\
\text { been removed. Definitions have been simplified. }\end{array}$ & $\begin{array}{l}\text { Waste electrical and electronic equipment } \\
\text { processing facilities were specified as a separate } \\
\text { item in Annex } 1 \text {. }\end{array}$ \\
\hline $\begin{array}{l}\text { A threshold value was brought over the total } \\
\text { press power and the capacity was changed } \\
\text { in the hammered metal forming plants. }\end{array}$ & $\begin{array}{l}\text { Some items that are not applicable have been } \\
\text { removed. }\end{array}$ & $\begin{array}{l}\text { Tanker cleaning facilities, PCB purification facilities } \\
\text { and end-of-life vehicle temporary storage facilities } \\
\text { have been included in Annex- } 2 \text {. }\end{array}$ \\
\hline $\begin{array}{l}\text { Substances covering operations with } \\
\text { explosives were combined. }\end{array}$ & $\begin{array}{l}\text { Items whose content was not understood have been } \\
\text { re-edited. }\end{array}$ & 9. Storage, Loading and Unloading of Materials \\
\hline $\begin{array}{l}\text { Scope has been clarified in pressure } \\
\text { forming processes. }\end{array}$ & $\begin{array}{l}\text { A lower threshold value for household appliances } \\
\text { production was given. }\end{array}$ & $\begin{array}{l}\text { The organic chemicals storage item and methanol } \\
\text { storage item were combined. }\end{array}$ \\
\hline \multirow{2}{*}{$\begin{array}{l}\text { Under the title of machine production and } \\
\text { repairment, the scope of production of } \\
\text { warehouse, tank container, etc. was made } \\
\text { on the raw material used instead of pieces, } \\
\text { the content was determined, the items were } \\
\text { combined. }\end{array}$} & $\begin{array}{l}\text { The item related to electrostatic powder painting } \\
\text { processes was added. }\end{array}$ & $\begin{array}{l}\text { Chlorine, liquid oxygen, ammonium nitrate, sodium } \\
\text { chlorate storage related items were removed from } \\
\text { Annex- } 2 \text {. }\end{array}$ \\
\hline & & $\begin{array}{l}\text { Material transfer, storage etc. the content of the } \\
\text { related item has been re-arranged and the scope } \\
\text { has been clarified. }\end{array}$ \\
\hline $\begin{array}{l}\text { The threshold value was given for the } \\
\text { grinding sanding plants. }\end{array}$ & & 10. Other Facilities \\
\hline \multirow[t]{4}{*}{$\begin{array}{l}\text { Ship/yacht building/maintenance and } \\
\text { repairment facilities were given a threshold. }\end{array}$} & & $\begin{array}{l}\text { A threshold value for urban/domestic wastewater } \\
\text { treatment plants has been adjusted. }\end{array}$ \\
\hline & & The item on air liquefaction plants was removed. \\
\hline & & $\begin{array}{l}\text { Cigarette / tobacco factories were valued at a lower } \\
\text { threshold value. }\end{array}$ \\
\hline & & $\begin{array}{l}\text { Tourism facilities have been given a lower } \\
\text { threshold value. }\end{array}$ \\
\hline
\end{tabular}


letter are generally similar, and the documents uploaded to the system in the application for the Compliance Letter are also requested at the PAC stage. In addition, the "EIA decision" issued by the MoEU is among the documents requested during the permit and license process.

At this point, it is important to note that after the necessary integration in the database of the Ministry is achieved, the request for duplicate documents can be prevented by automatically withdrawing from the electronic service network. In addition, the provision of the official documents automatically issued by various public institutions through the electronic service network of the Ministry after the system integration will contribute to the facilitation of the process. Efforts were also made to search for the so-called documents in the support, credit, incentive processes carried out by institutions and organizations and public tenders to increase the efficiency of the documents organized in the implementation of the regulation.

Within the scope of the study, flow charts describing the processes of determining the permit and license were also created. The scope determination processes is given in Figure 5 in the form of a flow diagram.

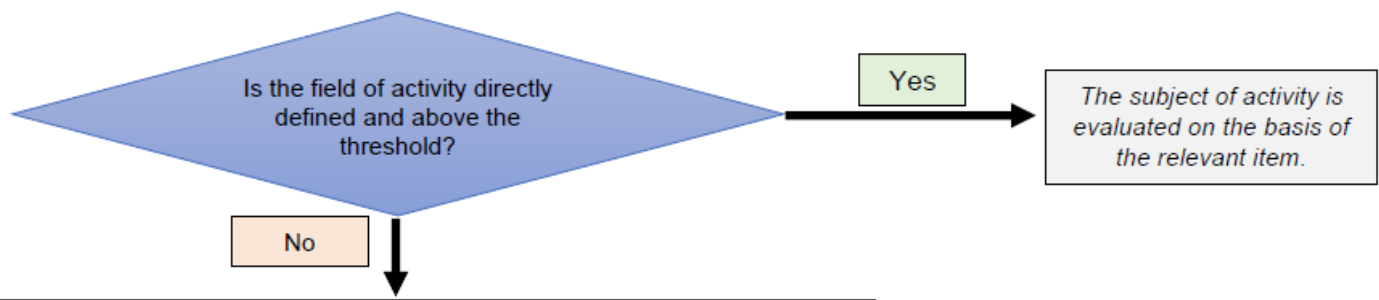

- Does the facility fall under the title of "Energy Industry" in terms of the total thermal power of the boilers depending on the fuel types?

- Does painting work in the facility?

- Is a surface treatment activity applied in the process?

- Is organic chemicals used as raw material in the process?

- Is there a process in the facility where chemical and / or chemical intermediates are not defined in the lists?

- Are chemical/gaseous substances stored for use in the process?

- Is there a storage of raw materials / products that cause dusting within the facility area?

- Does the activity have wastewater discharge to the receiving environment?

- $\quad$...... etc

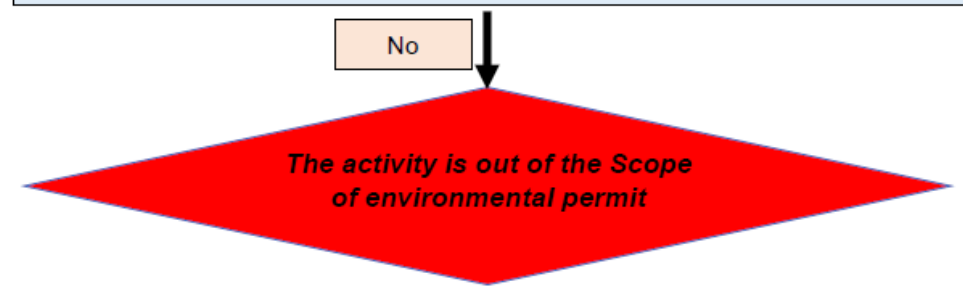

Figure 5. Simplified flow chart used in determining the scope of environmental permit

\section{Concluding Remarks}

Although the environmental permit licensing system varies from country to country, the aim of all this bureaucratic procedure is to control and minimize the environmental effects of the activities. While doing so, it is necessary to take into account the economic factors, which requires each country to fulfil the permit/license requirements in accordance with its own economic conditions.

On the other hand, there is a need to keep up with technological developments and to revise and update the articles of the regulation. In these revisions, requirements may arise such as determining the articles/titles that are no longer in use, but still existing in the regulations or on the contrary, the addition of a sector that has not yet been in place at the time the regulation entered into force. It may be necessary to characterize high environmental impact facilities as well as the low impacting ones with the introduction of new environmental control systems. The adaptation of the statements within the scope of the articles of the regulation to the developing technology conditions may be another issue that requires revision.

In parallel to the developments in technology, data storage and data mining are advancing rapidly. A process, which was carried out 10 years ago through a burden of hard-copies and signatures, can now be solved at the computer in a short time with integrated data processing systems throughout the country/city. Therefore, the permit/license procedures should be renewed by taking these issues into consideration. This situation will both facilitate the work of the activity owners who will fulfil their permit/license obligations, and will reduce the workload of the authorities and make the follow-up easier.

All amendments should be designed in a holistic, transparent and fair practice. It is important to contact the facility and to visit as many sectors as possible to witness the problems and to solve the problems encountered by the sector. On the other hand, it is necessary to make revisions to improve the environmental permit licensing procedure at certain 
periods by establishing a common platform where the opinions of experts, decision makers and other stakeholders who examine the permit/license documents and applications meet.

\section{Acknowledgements}

This study is based on the outcomes of the "Improvement of Environmental Permit and License Application Project" completed in 2020 with the participation and support of the TR MoEU, General Directorate of Environmental Impact Assessment, Permit and Inspection. We thank Ministry for their support.

\section{References}

Ahmetoğlu, S., Tanık, A. (2020). Management of Carbon Footprint and Determination of GHG Emission Sources in Construction Sector. International Journal of Environment and Geoinformatics, 7(2), 191-204, doi.10.30897 /ijegeo.726913

Akyüz, E. (2021). The Development of Environmental Human Rights, International Journal of Environment and Geoinformatics, 8(2), 218-225, doi.10.30897 /ijegeo.839725.

Bello Bugallo, P.M., Cristóbal Andrade, L., Magán Iglesias, A., Torres López, R. (2013). Integrated environmental permit through Best Available Techniques: evaluation of the fish and seafood canning industry. Journal of Cleaner Production, 47, 253-264.

Chakrabarti, S., Mitra, N. (2005). Economic and environmental impacts of pollution control regulation on small industries: a case study. Ecological Economics, 54,53-66.

EC (1996). European Commission, Council Directive 96/61/EC concerning integrated pollution prevention and control. Official Journal of the European Communities, L 257, 26-40.

EC (2006). European Commission, Reference Document on Best Available Techniques. IPTS, Seville.

EU (2010). Directive 2010/75/EU on industrial emissions (integrated pollution prevention and control). Official Journal of the European Communities, L 334, 17-119.

Farmer A., Armstrong J., Bassi S., Bowyer C., Farmer A., Gantioler S., Geeraerts K., Hjerp P., Lewis M., MPallemaerts M., Watkins E., Withana S. (2010). Sourcebook on EU Environmental Law, Prepared by IEEP for the EPE Banks.

Georgopoulou, E., Hontou, V., Gakis, N., Sarafidis, Y., Mirasgedis, S., Lalas, D.P., Loukatos, A., Gargoulas, N., Mentzis, A., Economidis, D., Triantafilopoulos, T., Korizi, K. (2008). BEAsT: a decision-support tool for assessing the environmental benefits and the economic attractiveness of best available techniques in industry. Journal of Cleaner Production, 16, 359373.

Mersin, K., Bayırhan, İ., Gazioğlu, C. (2019). Review of C02 Emission and Reducing Methods in Maritime Transportation, Thermal Science, 23(6).73-79. doi.org/10.2298/TSCI190722372M
Mersin, K., Bayırhan, İ., Gazioğlu, C. (2020). Analysis of the Effects of $\mathrm{CO} 2$ Emissions Sourced by Commercial Marine Fleet by using Energy Efficiency Design Index, Thermal Science, 24(1).187-197.

OECD (2007). Guiding Principles of Effective Environmental Permitting Systems.

Ribeiro, F. M., Kruglianskas, I. (2013). Improving environmental permitting through performance-based regulation: a case study of Sao Paulo State, Brazil, Journal of Cleaner Production, 46, 15-26.

Silvo, K., Melanen, M., Honkasalo, A., Ruonala, S., Lindström, M.(2002). Integrated pollution prevention and control e the Finnish approach. Resources, Conservation and Recycling, 35, 45-60

Söderholm, K., Söderholm, P., Helenius, H., Pettersson, M., Viklund, R., Masloboev, V., Mingaleva, T., Petrov, V. (2015). Environmental regulation and competitiveness in the mining industry: Permitting processes with special focus on Finland, Sweden and Russia. Resources Policy, 43, 130-142.

Taylor C., Pollard S., Rocks S., Angus A. (2012). Selecting Policy Instruments for Better Environmental Regulation: a Critique and Future Research Agenda. Environmental Policy and Governance, 22, 268-292.

Tian, X., Hu, Y., Yin, H., Geng, Y., Bleischwitz, R., (2019). Trade impacts of China's Belt and Road Initiative: From resource and environmental perspectives. Resour., Conserv. Recycl. 150, 104430.

Tokuşlu, A., Bayırhan, İ., Gazioğlu, C. (2020). Investigation the effect of sox emission reduction on transit ships emissions as of January 1, 2020, Thermal Science 24(1):149-155, doi.10.2298 /TSCI20S1149T

Torres Lopez, E. R., Doval Leira, R., Galera Martínez, M., Bello Bugallo, P. M. (2017). Integrated environmental permit through Best Available Techniques: Evaluation of the dairy industry. Journal of Cleaner Production, 162, 512-528.

Ülker, D., Bayırhan, İ., Mersin, K., Gazioğlu, C. (2020). A comparative $\mathrm{CO} 2$ emissions analysis and mitigation strategies of short-sea shipping and road transport in the Marmara Region, Carbon Management, 11(6): doi.10.1080/ 17583004. 2020.1852853.

Ülker, D., Ergüven, O., Gazioğlu, C. (2018). Socioeconomic impacts in a Changing Climate: Case Study Syria. International Journal of Environment and Geoinformatics, 5(1), 84-93, doi.10. 30897/ijegeo.406273

Wang, Z., Li, W., Li, Y., Qin, C., Lv, C., Liu, Y. (2020). The "Three Lines One Permit" Policy: An Integrated Environmental Regulation in China. Resources, Conservation and Recycling, 163, 105101.

Zhou, J., Wang, J., Jiang, H., Cao, D., Tian, R., Bi, J., Zhang, J., Cheng, X., 2019. A review of development and reform of emission permit system in China. Journal of Environmental Management, 247, 561569. 